\title{
Posição do Brasil no campo imperialista ${ }^{1}$
}

João Quartim de Moraes*

Resumo: A opressão colonial contra a qual os povos da Ásia e da África travaram vitoriosas lutas de libertação nacional não caracteriza a dominação imperialista sobre a América Latina. A luta antiimperialista, em nosso continente, não é, no essencial, anticolonial. Mas qual a dinâmica do desenvolvimento capitalista nos países explorados pelo imperialismo embora independentes enquanto nações?

Palavras-chave: libertação nacional, colônia, anti-imperialismo, monopólios, exploração imperialista.

Abstract: The colonial oppression against which the people of Asia and Africa fought victorious national liberation struggles do not characterize the imperialist domination on the Latin America. The antiimperialist struggle in our continent, is not, in essence, anti-colonial. But what is the dynamics of capitalist development in countries exploited by imperialism although independent while Nations?

Keywords: national liberation, colony, anti-imperialism, monopoly, imperialist exploitation.

\footnotetext{
${ }^{1}$ Texto originalmente publicado em duas partes nos números 25 e 26 da revista Debate, em 1977, e assinada por Fernando Andrade, pseudônimo do autor. Em relação às referências bibliográficas, foi mantido o formato original.

* Professor titular do departamento de filosofia da UNICAMP.
} 


\section{Prólogo breve}

No intervalo de trinta e seis anos que nos separam do momento em que o presente texto foi redigido a correlação de forças em escala mundial sofreu duas mudanças decisivas. O desmantelamento da URSS e do bloco socialista do Leste Europeu propeliu o bloco imperialista agrupado em torno dos Estados Unidos e de seus satélites da Otan a uma posição econômica e militar hegemônica. Mas a pujante ascensão econômica da China, a reconstrução do Estado russo após a década de saqueio promovida pelo megaladrão Boris Ieltsin, as desastrosas invasões do Iraque e do Afeganistão e a crise financeira de 2008 voltaram a modificar a situação internacional, desta vez a favor da luta anti-imperialista. As questões estratégicas dessa luta, do ponto de vista de nossa América, são hoje semelhantes às que prevaleceram na segunda metade do século passado: isolar os piores inimigos da emancipação dos povos, agrupados no cartel militar da Otan.

Serve o ensejo para agradecer a Danilo Martuscelli a iniciativa de repor o presente texto em circulação. Ele já o tinha feito em relação ao artigo "Dependência e imperialismo" ${ }^{2}$. É um grande encorajamento considerar que textos escritos no exílio durante os anos setenta possam ter alguma utilidade para nova geração de marxistas brasileiros.

J. Q. M., São Paulo, agosto de 2013.

\section{1 - Imperialismo e questão nacional}

Há cinco anos atrás, na polêmica sobre o programa e a tática da revolução brasileira que opôs a redação de Debate aos companheiros da Tendência Leninista da ALN, abriu-se uma longa discussão, proveitosa embora às vezes demasiada áspera, sobre a palavra de

2 Reeditado em Crítica Marxista (31) 2010, p. 23-36. 
ordem de "libertação nacional" que considerávamos - e continuamos considerando - inadequada para exprimir o conteúdo anti-imperialista da luta revolucionária em nosso país. Esta discussão se encontra nos números 8 e 10 de Debate e, não cabendo retomá-la aqui, a eles remetemos nossos leitores. Lembramos tão somente que ali defendemos a tese de que a palavra de ordem de "libertação nacional" só é correta para as nações oprimidas enquanto nações, enquanto que, segundo os companheiros da TL/ALN, ela constitui o principal elemento do programa revolucionário, já que preconizam uma "estratégia nacionallibertadora e democrática".

A esta questão voltamos em Debate-13 quando criticamos a estreiteza nacionalista das teses da AP sobre o caráter "neo-colonial" da dominação imperialista a que está submetido o Brasil. Mostramos, nesta oportunidade, o erro de análise que fundamenta estas teses: elas exprimem, por sua tenaz subestimação do desenvolvimento capitalista de nosso país uma variação nacional do "populismo" histórico, aquele mesmo que Lênin criticou profundamente no Desenvolvimento do capitalismo na Rússia.

A característica geral das concepções errôneas sobre a natureza da luta anti-imperialista que sustentam a palavra de ordem de "libertação nacional" é o fato de abandonarem, ao menos neste ponto, o terreno do materialismo dialético, na medida em que perdem de vista as determinações históricas concretas que caracterizam a opressão nacional. Não somos daqueles que pensam resolver um problema teórico do movimento revolucionário com meia-dúzia de citações de Marx ou Lênin. Nada de mais anti-marxista e anti-leninista do que o culto do texto sagrado. Mas quando nos defrontamos com um rebaixamento das aquisições teóricas e programáticas do movimento comunista internacional, parece-nos razoável, antes de mais nada, restabelecer os termos exatos em que determinado problema foi colocado e resolvido numa situação histórica concreta. No que se refere ao problema dito da "libertação nacional", dispomos de uma série de escritos de Lênin, datados de 1916 (isto é, da época da guerra mundial inter- 
imperialista, da traição social-democrata e da iminência da revolução socialista) posteriormente retomados no II Congresso da Internacional Comunista, que, se tivessem sido levados devidamente em conta por alguns de nossos comunistas, haveriam certamente evitado a grande confusão que reina ainda sobre o assunto em nossa esquerda.

Em dois destes escritos, A revolução socialista e o direito das nações a disporem de si próprias e Uma caricatura do marxismo (LENIN, Obras, vols. 22 e 23) distinguem-se, em relação à questão nacional, três tipos de países. "O primeiro tipo, são os países avançados da Europa Ocidental (e da América) onde o desenvolvimento nacional pertence ao passado. O segundo tipo, é a Europa do Leste, onde ele pertence ao presente. O terceiro, são as semi-colônias e colônias onde ele pertence, em larga medida, ao porvir (grifado no original)" (LENIN, Obras, vol. 23, p. 39). Qual a natureza deste "movimento nacional" que constituía, em 1916, o presente da Europa do Leste e o futura das colônias e semicolônias? Que objetivos o caracterizam? Fundamentalmente "o despertar das massas para a posse da língua nacional e de sua literatura (que constitui condição necessária e corolário do desenvolvimento completo do capitalismo, da penetração da troca até a última família camponesa)". Nos países onde a "questão nacional" é tarefa objetiva, a "defesa da pátria" "pode ainda ser a defesa da democracia, da língua materna, da liberdade política contra as nações opressoras, contra a Idade Média" (LENIN, Obras, vol. 23, p. 40-41). Inútil salientar que ao recusarmos a palavra de ordem de "libertação nacional" para as nações que por disporem de sua própria língua, de seu próprio território, de independência política, não são oprimidas enquanto nações, nada mais estávamos fazendo que expor, no vocabulário político contemporâneo, a mesma concepção. Constitui grave confusão tratar da mesma forma os países economicamente dominados pelo imperialismo com os países e povos dominados enquanto povos. A Argentina, escreve Lênin,

\begin{tabular}{l|l}
\hline 16 & Posição do Brasil no campo imperialista
\end{tabular} 
[...] é de fato uma "colônia comercial" da Inglaterra, Portugal é de fato um "vassalo" da Inglaterra, etc. Isto é exato dada a dependência econômica em relação aos bancos ingleses, o açambarcamento pela Inglaterra das estradas de ferro locais, das minas, das terras, etc. -tudo isso faz destes países "anexações" da Inglaterra do ponto de vista econômico sem que haja violação de sua independência política. Ora, chamamos livre disposição das nações à sua independência política (LENIN, Obras, vol. 23, p. 46. Grifos nossos).

Como se vê, a questão decisiva para Lênin é a da independência política: o "movimento nacional" se determina por esta tarefa histórica que em absoluto não se confunde com aquela dos países onde a exploração econômica imperialista não viola a independência política (exemplos de Portugal e Argentina).

Do ponto de vista do materialismo dialético, é evidente que não há independência política absoluta, que um país economicamente dependentenãoé politicamenteindependentenomesmosentidoqueum país imperialista. Mas "dialética" não significa confusão de conceitos. O que diferencia objetivamente a situação de um país economicamente independente daquela de uma nação oprimida enquanto nação é que nesta a luta revolucionária assume necessariamente a forma de libertação nacional, de conquista da "livre disposição" no vocabulário da época.

Não é difícil avaliar as consequências políticas práticas destas distinções teóricas. Basta observar a dinâmica da luta revolucionária em nossa época, em particular na Ásia e na África (mundo árabe incluído), para perceber que as grandes vitórias revolucionárias dos povos destes continentes nas últimas décadas estiveram intimamente ligadas à resolução da questão nacional. Enquanto que a estagnação e mesmo os retrocessos da luta revolucionária na América Latina (onde a Revolução Cubana continua a constituir um fenômeno excepcional) 
não se compreendem (salvo para as explicações "geopolíticas" tipo "teoria dos dominós") sem levar em conta que com raras exceções (Panamá por causa da Zona do Canal, Porto Rico e as colônias francesas) a "questão nacional" como tal já foi resolvida na América Latina (mal resolvida, já que levou à balkanização e implicou em guerras fratricidas teleguiadas pelo imperialismo) mas, de qualquer modo, historicamente superada. A luta anti-imperialista, em nosso continente, não é, no essencial, uma luta de libertação nacional.

É neste sentido extremamente interessante a auto-crítica teórica a que procede Régis Debray em seu livro A crítica das armas. Ele aí desenvolve (p. 37-52) uma análise no fundamental coincidente com a que expusemos acima, com uma diferença apreciável, a saber que na conclusão (p. 52) se refere ao "paradoxo de um movimento histórico do qual o anti-imperialismo é a dominante e o eixo diretor, mas que não é mais um movimento de libertação nacional". Em nosso entender este paradoxo é mais aparente que real. A "dominante" e o "eixo diretor" do movimento revolucionário é a luta pela democracia; é nela que se concentra a dinâmica de ruptura com a ordem social e portanto com a base econômica existente. Exatamente porque são politicamente independentes, as nações latino-americanas enquanto nações, não têm (com as exceções já apontadas) liberdade política para conquistar. Mas porque nelas as classes dominantes através da ditadura militar negam liberdade política às classes populares, estas têm a democracia para conquistar: o grande mérito de ter pela primeira vez compreendido e formulado este traço essencial da luta revolucionária em nossas condições históricas cabe sem dúvida alguma ao Projeto de Plataforma Política de Debate-12 (abril de 1973). Também pela primeira vez se colocou ali a questão da interpenetração das tarefas democráticas e antiimperialistas no programa de democracia revolucionária. O que até agora não tinha sido feito, nem na Plataforma para a união dos comunistas, nem em nosso artigo recente sobre a Democracia revolucionária (Debate-24), é expor sistematicamente o problema da luta anti-imperialista a partir da análise da posição do Brasil no interior do campo imperialista internacional. $\mathrm{O}$ presente artigo constitui uma contribuição neste sentido. 


\section{2 - Formas de exploração imperialista}

A história moderna do colonialismo e do imperialismo reproduziu em escala mundial e em função do desenvolvimento do capitalismo nas metrópoles, as diferentes formas do Capital entendido como categoria econômica geral. É sabido que historicamente (na Antiguidade greco-romana, por exemplo) o Capital se apresentou sobretudo como Capital Comercial e Usurário. Também assumiu a forma de Capital Produtivo na medida em que transformou o produtor direto, pela escravidão, em Capital Fixo, em objeto ou mais exatamente em instrumento de produção. "O boi é o escravo do pobre" escreveu Aristóteles em sua Política exprimindo assim a degradação do trabalhador (condição subjetiva, humana, na produção). Ninguém ignora como a história moderna da colonização reproduziu estas formas arcaicas do Capital. A transformação do colonialismo capitalista em colonialismo imperialista, e de um modo geral, a transformação imperialista do capitalismo não aboliu todas as formas arcaicas de exploração, mas alterou qualitativamente seu significado e sua importância relativa. Elas se integram no sistema geral de exploração imperialista e passaram a evoluir em função da dinâmica fundamental da superacumulação monopolista, que constitui a mola do capitalismo contemporâneo.

Algumas formas da exploração colonial foram eliminadas, outras reintegradas pelo imperialismo. A exploração do Capital Comercial, por exemplo, que constituiu o fator dinâmico da colonização na aurora do capitalismo, se apresenta hoje como "intercâmbio desigual". Mas o sobre-lucro comercial que representou elemento decisivo da acumulação capitalista primitiva, hoje tem papel secundário em relação à exploração direta, pelos monopólios imperialistas, da força de trabalho dos países dominados pelo imperialismo. Por outro lado, o desenvolvimento do capitalismo nas colônias e a concentração capitalista nas metrópoles aboliram a escravidão. O imperialismo conservou e reintegrou formas de exploração do 
mundo colonial herdadas de fases anteriores do desenvolvimento histórico do capitalismo, mas subordinou-as à lógica da acumulação monopolista nos países dominantes, eliminando aquelas que não mais correspondiam às necessidades da reprodução do processo produtivo e da valorização do Capital. As formas de exploração conservadas e reintegradas são pois historicamente anteriores mas estruturalmente secundárias à extorsão direta de mais-valia das massas trabalhadoras dos países dominados.

Dos cinco traços essenciais do imperialismo, tais com os definiu Lênin em seu clássico estudo de 1916 (concentração da produção e do capital criando monopólios; fusão do capital bancário e do capital industrial criando o "capital financeiro" e a oligarquia financeira; predominância da exportação de capitais sobre a exportação de mercadorias; formação de "uniões internacionais monopolistas de capitalistas" repartindo entre si o mundo - Lênin descobriu a importância das "multinacionais" mais de meio século antes do que alguns "profundos" economistas atuais - e término da divisão territorial do mundo entre as grandes potências capitalistas - LENIN, O imperialismo, estágio supremo do capitalismo, in: Obras, vol. 22, p. 287) somente o último perdeu atualidade graças ao formidável desenvolvimento da luta de libertação na Ásia e na África. As demais formação de monopólios e do capital financeiro, exportação de capitais e domínio da economia mundial capitalista pelas "multinacionais" como se diz hoje - continuam a constituir a essência do capitalismo contemporâneo enquanto sistema internacional de produção e de circulação.

\section{3 - Exploração monopolista e exploração imperialista}

Lênin desenvolveu sua teoria do imperialismo do ponto de vista da lógica interna da evolução histórica do capitalismo. A formação dos monopólios correspondeu à constituição, nos países avançados do limiar do século XX, "de um enorme excedente de capitais", que

20 Posição do Brasil no campo imperialista 
evidentemente, não poderia ser consagrado à elevação do nível de vida das massas num dado país, porque

[...] disso resultaria uma diminuição dos lucros para os capitalistas, mas a aumentar estes lucros pela exportação de capitais para o exterior, nos países subdesenvolvidos. Os lucros são aí em geral elevados, devido à insuficiência de capitais, o preço da terra é relativamente baixo assim como os salários e as matérias-primas são baratas (LENIN, O imperialismo, estágio supremo do capitalismo, in: Obras, vol. 22, p. 260-261).

Correspondendo à concentração da produção e do capital, bem como à sua centralização (massas cada vez maiores de capital são apropriadas por uma restrita oligarquia financeira) a transformação imperialista do capitalismo constitui uma fase qualitativamente distinta da evolução histórica deste modo de produção e não uma simples e contingente forma de "política externa" de alguns países dominantes. A polêmica que desenvolve contra o oportunismo social-democrata repousa justamente sobre a afirmação do caráter necessário, objetivamente determinado, desta evolução. As metrópoles capitalistas não são imperialistas porque seus governos teriam optado por uma política belicista e expansionista, mas porque, nestes países, o capitalismo atingiu um grau de desenvolvimento que engendra os monopólios.

Escrevendo durante a guerra mundial inter-imperialista, Lênin só se refere indiretamente aos efeitos da dominação imperialista sobre os países sobre os quais ela se exercia. Seu objetivo era explicar a natureza de classe da guerra de 1914-1918, bem com sua significação histórica - de antevéspera da revolução proletária mundial - e não as consequências concretas da exportação de capitais sobre o desenvolvimento econômico dos três continentes dominados (o "terceiro mundo" na linguagem corrente atual). Parecia-lhe - bem como a todos os revolucionários 
comunistas da sua época - que a vaga revolucionária suscitada pela guerra mundial iria varrer da cena histórica, a curto prazo, a ordem capitalista internacional e por isso mesmo não contemplou a hipótese de um período histórico de coexistência de um poder soviético e de um campo imperialista que prolongaria, por prazo indeterminado, a exploração dos povos coloniais e dependentes. Há, portanto, sem dúvida, uma lacuna, perfeitamente compreensível, em sua teoria do imperialismo (que, no entanto, permanece verdadeira e atual em seus aspectos fundamentais) que, em nossos dias, deu lugar às "teorias da dependência”, cuja contribuição é inegável, em que pesem os incontáveis contrabandos ideológicos de que estava eivada, para a compreensão da posição de nosso continente no interior do campo imperialista internacional.

Não é aqui o lugar para desenvolvermos a crítica das noções em que se baseia a "teoria da dependência" tal como foi desenvolvida por correntes da esquerda latino-americana mais ou menos próximas senão da teoria, ao menos do vocabulário marxista. Já o fizemos alhures, e de resto alguns de seus melhores representantes - F. H. Cardoso, por exemplo - têm manifestado reservas crescentes diante da inflação especulativa de doutrinas e doutrinários do "capitalismo dependente". Voltaremos a esta questão quando tratarmos do "sub-imperialismo", que um destes doutrinários (R. Marini) definiu como a "fase imperialista do capitalismo dependente". O que agora nos importa salientar é que o problema (mal) tratado pelas teorias da dependência é um problema real, a saber, o da dinâmica do desenvolvimento capitalista nos países explorados pelo imperialismo embora independentes enquanto nações. Historicamente, a primeira grande resposta que lhe deu o movimento comunista na América Latina foi a de que a dominação imperialista representaria fator de atrofia do desenvolvimento capitalista nos países sobre os quais ela se exerce. Donde a tese, teoricamente unilateral e politicamente oportunista de direita de que as burguesias nacionais destes países poderiam se aliar ao proletariado na etapa "nacional e democrática" da revolução. (Desvio que suscitou nos anos 1960, 
o desvio oposto, menchevique de "esquerda" - incarnado no Brasil sobretudo pela POLOP - que constituiu na negação simplista e pueril da especificidade da dominação imperialista, confundindo com a dominação capitalista em geral). É pois da maior importância, na luta pelo programa marxista e pela reunificação dos comunistas, resolver teoricamente a questão dos efeitos específicos da dominação imperialista sobre o desenvolvimento do capitalismo em nosso país.

O imperialismo é o capitalismo monopolista. A dominação imperialista é a dominação do capitalismo monopolista. No entanto, os monopólios norte-americanos não dominam a economia e a sociedade norte-americana da mesma forma como dominam a economia e a sociedade mexicana, brasileira, boliviana, sul-coreana, marroquina, zairense, etc. Intuitivamente, a diferença parece óbvia. As coisas se complicam um pouco quando tentamos sair das intuições (isto é, das certezas puramente subjetivas) e determinar com rigor e clareza em que consiste esta diferença. O operário norte-americano é explorado pelos monopólios de seu país. Mas não no mesmo grau e nas mesmas condições que o operário (e o camponês) brasileiro. O que complica mais ainda a coisa - e complica tanto que nem mesmo os doutos pensadores marxistas da POLOP e áreas próximas deram mostras de ter sequer compreendido a existência do problema - é que mesmo no interior dos Estados Unidos - para ficarmos com o exemplo do país que exerce a supremacia do interior do campo imperialista a exploração monopolista não se identifica à exploração capitalista em geral. "A formação de monopólios não teria sentido algum se eles não assegurassem uma taxa de lucro mais elevada", observou com razão o economista soviético Eugene Varga. O lucro monopolista é pois estruturalmente superior ao lucro do capital não-monopolista. Os monopólios se apoderam de uma parte do sobre-trabalho social mais que proporcional ao capital que investiram. O que implica que a burguesia que não exerce monopólio se apodera de uma parte menos que proporcional deste sobre-trabalho, ou, o que vem ao mesmo, 
seu capital se valoriza a uma taxa média inferior à taxa do lucro monopolista.

A observação corrente confirma, via de regra, que os salários pagos aos operários pelos monopólios não são, dentro do mesmo país ou da mesma região, em média inferiores aos salários pagos pelas empresas não-monopolistas. Isto é, não se pode explicar o lucro monopolista enquanto distinto, numa mesma sociedade e num mesmo sistema econômico, do lucro não-monopolista, por uma maior taxa de exploração. Não existe, contrariamente ao que afirma o "economismo esquerdista" uma lei geral da alta tendencial da taxa de exploração, no sentido em que realmente existe, como mostrou Marx no livro III do Capital, uma lei geral da baixa tendencial da taxa de lucro. O lucro monopolista se realiza na esfera da redistribuição, entre os capitalistas da massa total de mais-valia produzida numa sociedade determinada - em última análise no sistema internacional capitalista, mas por enquanto não estamos ainda raciocinando "em última análise" - isto é ao nível da perequação da taxa geral de lucro - que se cinde numa taxa média de lucro monopolista e numa taxa média de lucro não-monopolista graças justamente à posição de predomínio conquistada pelo grande capital sobre a base de concentração da produção e da fusão do capital industrial e bancário.

Devemos então concluir que a exploração monopolista se confunde com a exploração imperialista? Evidentemente não. Mas como fundamentar teoricamente esta evidência intuitiva? Se o salário pago por um monopólio a seus trabalhadores não é num mesmo país inferior em média ao salário pago por uma empresa não-monopolista, o salário pago pelo mesmo monopólio aos trabalhadores do país capitalista metropolitano é " $\mathrm{n}$ " vezes superior ao salário pago, por uma mesma atividade aos trabalhadores do país capitalista dominado. Segundo a Havard Business Review (The Business Outlook for South East Asia, publicado em maio-junho 1973), o salário horário de um operário industrial variava de 2,5 dólares nos Estados Unidos a 0,1 dólar na Indonésia passando por 0,9 dólares no Japão, 0,37 no México e 0,6

\begin{tabular}{l|l}
\hline 24 & Posição do Brasil no campo imperialista
\end{tabular} 
em Taiwan. Estas cifras (cuja seriedade não se pode pôr em dúvida) poderiam se completar por inúmeras outras - por exemplo, quanto ganha exatamente pela mesma tarefa um operário brasileiro e um operário alemão da Volkswagen? Aqui temos realmente uma superexploração da classe operária, cujas formas mais claras e historicamente mais recentes, são de um lado a imigração de grandes massas proletárias dos países capitalistas atrasados e dependentes, e mesmo de países de orientação e regime socialista mas economicamente atrasados e com uma população excedentária, de outro, a exploração diferencial (= super-exploração) do proletariado das nações dominadas pelos monopólios ali instalados. (Uma distinção importante, que infelizmente falta espaço para desenvolver aqui é a que concerne a implantação propriamente dita dos monopólios imperialistas nos países dominados - o caso da indústria automobilística no Brasil, por exemplo, - da simples "industrialização por empreitada" - se assim se pode traduzir o fenômeno que em inglês se denota pela expressão sub-contracting e em francês sous-traitance - quando os monopólios se contentam em deslocar para os países dominados uma parte da fabricação de determinado produto, justamente aquela que incorpora muita mão de obra pouco qualificada com o único e exclusivo objetivo de se beneficiar com os salários baixíssimos da mão de obra local).

$\mathrm{O}$ que têm em comum as diversas formas de exploração imperialistas acima enumeradas é o fato (1) de se realizarem diretamente ao nível do processo produtivo (contrariamente às formas mais antigas de exploração - pilhagem dos recursos naturais, intercâmbio desigual - que não visam diretamente à super-extorsão do sobre-trabalho do proletariado dominado) e (2) de implicarem, como fator determinante, a exploração diferencial: se os monopólios japoneses e norte-americanos se dirigem ao Sudeste Asiático, os norteamericanos ao México e ao Caribe, os oeste-europeus à África, para lá instalarem seções de montagem de aparelhos elétricos, de autopeças, de produtos têxteis, de equipamentos elétricos, de fibras sintéticas, etc. é porque aumentam consideravelmente seus lucros pagando 
pelo mesmo trabalho um salário muito menor. Podemos pois definir a exploração imperialista naquilo que tem ao mesmo tempo de mais fundamental e de mais atual como a super-exploração do proletariado das nações dependentes, ou ainda a exploração monopolista diferencial dos trabalhadores do "terceiro mundo". ${ }^{3}$

\section{4 - A posição do Brasil ${ }^{4}$}

Oimperialismo não suprime a lógica objetiva do capitalismo, nem suas contradições. Não suprime, por exemplo, nem a concorrência nem a anarquia da produção, mas cindindo a burguesia em monopolista e não-monopolista, estabelece um novo tipo de concorrência (desigual entre os monopólios e as empresas não-monopolistas e "competitiva" entre os monopólios) e uma nova forma de anarquia (não é exato dizer que os monopólios produzem de costas para o mercado, como era a regra na fase pré-monopolista, na qual os capitalistas individuais não conheciam com precisão a demanda solvável para os artigos que produziam; mas como produzem para valorizar o Capital e não para satisfazer as necessidades sociais, estabelecem um novo tipo de anarquia impondo o consumo daquilo que produzem em detrimento daquilo que corresponderia à verdadeira satisfação do "consumidor").

Do mesmo modo, na distinção que efetuamos entre exploração monopolista e exploração imperialista, cabe deixar claro que esta inclui todos os elementos daquela, agravados pelo caráter diferencial da espoliação econômica dos povos dominados pelos povos dominantes.

Vimos com efeito que é próprio à exploração monopolista (enquanto forma específica de exploração capitalista) incidir sobre a economia como um todo, já que todas as classes e camadas não-

\footnotetext{
${ }^{3}$ Aqui encerra-se a parte do artigo publicada no número 25 da revista Debate. (Nota do editor).

${ }^{4}$ Aqui inicia-se a parte do artigo publicada no número 26 da revista Debate. Observa-se que neste número o título do artigo é sutilmente modificado de "A posição do Brasil no campo imperialista" para "O Brasil no campo imperialista - II" (Nota do editor).
} 
monopolistas da sociedade, cada uma à sua maneira, são exploradas pelo capital financeiro, entendido no sentido leninista de fusão do capital industrial e do capital bancário. Por isso, para completar a definição inicial da exploração imperialista, exposta na seção anterior deste artigo, é necessário ter presente que ela é ao mesmo tempo uma exploração monopolista e uma exploração diferencial (= super-exploração).

Grande parte da longa polêmica há décadas em curso dentro de nossa esquerda sobre a posição do Brasil no campo imperialista, que levou a concepções tão opostas quanto a do "sub-imperialismo" e a da "semi-colônia" repousa sobre a incompreensão do duplo caráter da dominação exercida pelos grandes monopólios sobre nossa sociedade. Esclareçamos antes de mais nada que em nada nos interessa uma disputa em torno de palavras e que não nos escapa em muitos aspectos (pretensão à supremacia regional, à ingerência nos assuntos internos de países vizinhos mais fracos, expansionismo econômico no "Cone Sul", etc.) a expressão "sub-imperialismo" dá uma imagem jornalística de uma realidade econômica e política de nosso país. O mesmo vale, em outros aspectos, para a expressão "semi-colônia". A miséria e a super-exploração das massas brasileiras, a dominação dos grandes monopólios multinacionais, a subordinação (atualmente atenuada) aos Estados Unidos, o pesado tributo pago ao capital estrangeiro, são elementos que exprimem o efeito da dominação imperialista sobre o Brasil e tornam compreensível o emprego - também jornalístico ou agitativo - da expressão "semi-colônia". No entanto, ambas as fórmulas são unilaterais, isto é, apresentam aspectos isolados da questão como se fossem o conjunto da questão, apresentam um lado da realidade como se tivessem apresentando todos os lados da realidade. Neste sentido e nesta medida, constituem teses falsas que devem ser refutadas, isto é, combatidas no campo teórico.

A doutrina do sub-imperialismo foi objeto de vários tipos de crítica, inclusive algumas direitistas, como aquela desenvolvida por F. H. Cardoso em Estudos Cebrap n. 8, o qual entre outras coisas nega a super-exploração do proletariado dos países dominados (através 
de uma argumentação extremamente superficial, baseada numa completa confusão entre "mais-valia absoluta" e super-exploração, como se esta não fosse possível sobre a base da mais-valia relativa: Cardoso simplesmente ignora o caráter estruturalmente diferencial da exploração dos proletários dos países dominados...). Ao mesmo tempo, o teórico do Cebrap ataca com inteligência - e com razão em muitos pontos - o esquematismo simplista dos doutrinários do subimperialismo brasileiro, em particular de R. Marini, cujo opúsculo sobre "El sub-imperialismo brasileño" confunde internacionalismo proletário com bajulação dos sentimentos nacionalistas de outros países latino-americanos e se esquece ao denunciar, de Santiago, o expansionismo brasileiro, de que o Chile arrebatou pela via das armas as províncias marítimas bolivianas (e algumas peruanas), de que também a Argentina desenvolve uma diplomacia de grande potência regional e sobretudo de que a principal vítima do "desenvolvimento monopolista dependente" do capitalismo no Brasil são os operários e camponeses de nosso país. O oportunismo "de esquerda" da doutrina sub-imperialista permitiu pois ao direitismo social-democrata misturar o joio com o trigo e por no mesmo saco as especulações de R. Marini e a exploração diferencial do trabalhador brasileiro. Lênin, ao dar à noção de imperialismo sua significação histórica de época do capitalismo monopolista e da revolução socialista internacional, teve como preocupação central determinar sua incidência sobre a dinâmica da luta revolucionária e neste sentido elucidou não somente a dinâmica econômica da expansão imperialista (a exportação de capitais como alternativa à super-acumulação e à baixa tendencial da taxa de lucro), mas também sua dinâmica política em particular no referente às suas consequências sobre o movimento operárioe revolucionário, mostrando como nos países capitalistas metropolitanos, a burguesia monopolista corrompeu uma parcela importante da classe operária - a "aristocracia operária" - favorecendo o avanço do oportunismo no movimento operário e socialista da época (ao qual sucumbiu o próprio "herdeiro" intelectual de Marx e Engels, Kautsky). A confusão mais grave que 
cria a doutrina do "sub-imperialismo" brasileiro é justamente esta: do mesmo modo que o imperialismo engendra a aristocracia operária devemos considerar que o "sub-imperialismo" engendra uma "subaristocracia" operária? Há uma camada importante do proletariado brasileiro, que está corrompido por partilhar indiretamente da "sub-exploração" a que o Brasil submeteria outros povos da América Latina? O próprio Marini, ao apontar a super-exploração do proletariado brasileiro parece crer que não. Mas em princípio, a existência de uma massa proletária super-explorada não é incompatível com a existência de uma camada minoritária "aristocratizada". Desconhecemos as eventuais informações demonstrando que tal camada existe (lembrando que se trata de uma camada superior da classe operária e não de uma burocracia sindical corrompida, porque ninguém ignora o fenômeno da pelegagem, só que nem Marini nem ninguém mais mostrou até agora que os pelegos são a expressão de uma problemática da aristocracia operária: o que consta é que são impostos ao sindicalismo pelo terror policial-militar).

A doutrina do semi ou neo-colonialismo nega o desenvolvimento capitalista do Brasil, que já atingiu o estágio da concentração monopolista da produção. Nega que a burguesia brasileira dispõe de uma base própria de dominação de classe, considerando que a ditadura militar é mera emanação do imperialismo norte-americano. Nega portanto que a forma de Estado seja hoje a expressão das necessidades da concentração monopolista acelerada, considerando que a classe dirigente ainda é a oligarquia latifundiária. Nega a realidade e afirma uma quimérica unidade da nação brasileira como tal. Vê a contradição principal fora da nação, quando ela atravessa a estrutura mesma da produção. Não pode ser levada a sério, embora, comparada à doutrina do "sub-imperialismo" tenha ao menos o mérito indiscutível de salientar a espoliação a que é submetida a grande massa do povo brasileiro.

Destas considerações decorre que o Brasil está inserido no campo imperialista internacional como país capitalista explorado 
pelos monopólios multinacionais, mas cuja burguesia tem interesses econômicos e políticos próprios e participa, tanto quanto os monopólios estrangeiros, da exploração dos trabalhadores. Não que se deva identificar a posição da burguesia monopolista brasileira à dos monopólios multinacionais. Os monopólios brasileiros correspondem ao grau do desenvolvimento do capitalismo em nosso país; não dispõem, como os monopólios multinacionais, do controle da inovação tecnológica; não realizaram a integração da pesquisa científica à produção e, sobretudo, a massa de capital que concentram e centralizam é incomparavelmente inferior àquela da alta finança imperialista. Sua esfera de atuação, em que pese o "export drive" de Delfim Neto e consortes, é principalmente nacional, no melhor dos casos regional: são monopólios domésticos. Donde sua possibilidade muito limitada de se organizar em cartéis, trustes e holdings pesando na correlação de forças entre os monopólios internacionais. Donde sua dependência em relação aos fundos públicos, tanto mais que não podem contar, como ocorre com as multinacionais instaladas no país, com financiamento direto e imediato do exterior. Se o traço mais característico da transformação monopolista do capitalismo é a interpenetração do capital bancário e industrial e a formação sobre esta base do capital financeiro, então o capitalismo de monopólios brasileiro é singularmente atrofiado, posto que o chamado "setor financeiro" brasileiro constitui sobretudo um mecanismo de especulação e de usura ao qual a indústria não recorre, salvo para financiar capital de giro. Vale dizer que no Brasil a integração dos grandes bancos e da grande indústria não se verificou, por força do caráter atrasado e dependente do desenvolvimento capitalista: o capital bancário se dirigiu para as negociatas das "financeiras" e o industrial teve de se contentar com as brechas que lhe deixam os monopólios multinacionais. A supremacia da oligarquia financeira imperialista sobre o capitalismo monopolista brasileiro é a causa fundamental da exploração imperialista a que está submetida a economia brasileira como um todo, de sua dependência 
financeira, a qual se exprime, muito imperfeitamente, em termos contábeis, nos quase 30 bilhões de dólares da dívida externa.

A inferioridade econômica da burguesia monopolista brasileira diante dos monopólios imperialistas constitui a chave de compreensão de sua atitude contraditória em relação ao setor estatal da economia. A fórmula do ex-ministro da indústria Severo Gomes é neste sentido lapidar: "hoje, desestatizar é desnacionalizar". Hoje e sempre. Sem capitalismo de Estado, o capitalismo de monopólios seria inviável no Brasil. Para não "desnacionalizar", a burguesia brasileira teria de fortalecer a economia nacional, controlando estritamente os investimentos estrangeiros e a remessa de lucros, ampliando o mercado interno (o que supõe antes de mais nada o fim do arrocho e a aplicação no campo da consigna "a terra para quem nela trabalha"), aplicando uma decidida política de emancipação econômica e para isso enfrentando toda sorte de chantagens e pressões por parte do imperialismo. Ora, foi por ter apenas preconizado esta política que Jango foi derrubado. O que tem mostrado, neste sentido, a evolução política recente da burguesia brasileira, é um maior receio do capitalismo de Estado (o qual, embora a serviço da burguesia, contém em seu princípio a negação da propriedade privada burguesa sobre os grandes meios de produção e aparece portanto como arma de dois gumes) do que dos monopólios multinacionais (que a ameaçam no terreno econômico, mas não no terreno político e ideológico). Ela precisa da estatização capitalista contra as multinacionais, mas precisa das multinacionais para manter a lógica da acumulação monopolista, já que a recíproca da tese de Severo Gomes, se não for verdadeira, é pelo menos tida como tal pelos círculos politicamente predominantes da alta burguesia: hoje, "nacionalizar" seria estatizar!

A relação da burguesia como um todo e da burguesia monopolista como camada dominante da classe dominante com o Estado não pode ser concebida nem de maneira puramente "instrumental" (já que o Estado é, ele também, uma realidade social e particularmente no Brasil, uma realidade econômica), isto é, o Estado não está a serviço da 
burguesia no mesmo sentido que o bisturi está a serviço do cirurgião ou o freio a serviço do motorista, nem de maneira análoga à das burguesias dos países dominantes com seus Estados respectivos. Desenvolver cada um destes dois pontos implicaria em pelo menos dois artigos tão longos como este. Somos pois obrigados a ser extremamente concisos, em detrimento da clareza, mas não temos infelizmente alternativa.

Sobre o caráter não-instrumental da relação classe dominante/ Estado, notemos tão somente que a despeito dos exageros interessados a que deu recentemente a campanha "anti-estatizante" movida pelos círculos mais poderosos da direita liberal, sem dúvida alguma a centralização do poder de Estado nas mãos da burocracia militar favoreceu o fortalecimento do setor estatal da economia, tanto no domínio financeiro (crédito à indústria) quanto na esfera diretamente produtiva (os dados sobre a importância das empresas estatais nos ramos mais determinantes da infraestrutura industrial e da indústria pesada são suficientemente conhecidos). Donde um elevado grau de autonomia do Estado em relação à burguesia, inclusive à burguesia monopolista. Sem essa autonomia não se compreenderia a exasperação da alta burguesia paulista, analisada no editorial de Debate- 25 .

Sobre a não-analogia entre a relação burguesia monopolista/ Estado no Brasil e nos países capitalistas metropolitanos, além de causas determinadas por uma distinta correlação de forças entre o Trabalho e o Capital (por exemplo, a colaboração de classes incluindo a gestão socialdemocrata do Estado capitalista, como ocorre na Alemanha Ocidental principal potência capitalista europeia), o que cabe salientar é que o Estado brasileiro garante a sobrevivência como classe da burguesia brasileira, mas não a das burguesias dos países capitalistas metropolitanos. A revolução no Brasil porá fim à dominação de classe da burguesia do Brasil, mas, por definição, só afetará diretamente os investimentos estrangeiros em nosso país. Baixarão provavelmente as cotações das ações e os dividendos destes investidores, mas nem por isso eles perderão suas posições de classe em seus países respectivos. Em suma, a sobrevivência da burguesia e do Estado capitalista 
brasileiros são mutuamente interdependentes, e portanto o vínculo que os une é indissociável. Por isso, se o Estado capitalista brasileiro favorece as multinacionais muitas vezes em detrimento dos interesses imediatos da burguesia brasileira é porque assim o exigem as condições da acumulação monopolista acelerada, é porque, como tal, o capitalismo de monopólios no Brasil só pode se manter em estreita articulação com o sistema imperialista internacional. E aqui reside um dos grandes equívocos da doutrina do "semi-colonialismo": não é por ser a emanação direta da dominação política estrangeira, mas por estar a serviço de uma burguesia economicamente dominada pelo capital estrangeiro que a política econômica do regime militar satisfaz, no essencial, às exigências dos monopólios multinacionais. Ela promove o encontro da fome de divisas do capitalismo brasileiro e da vontade de comer sobre-lucros do capital financeiro imperialista. E a nota do festim é paga com a miséria das massas trabalhadoras.

Na medida em que a burguesia brasileira e a alta finança imperialista constituem forças distintas com interesses nem sempre convergentes e muitas vezes opostos, suas relações não devem ser concebidas estaticamente como uma pura e simples "integração imperialista" (expressão utilizada pelo socialista uruguaio Vivian Trias, um dos inventores da doutrina do "sub-imperialismo" brasileiro) ou como uma "internacionalização do mercado interno", fórmula mais rebuscada (utilizada por exemplo por F. H. Cardoso), mas que como a anterior, tem o grave defeito de encobrir o caráter contraditório da posição do Brasil no campo imperialista, diluindo-lhe a dinâmica específica numa generalização a-histórica, ou pelo menos abstrata. Com efeito, também a Coréia do Sul, o Zaire e a Nicarágua - para tomar exemplos ao acaso - estão "integrados" ao imperialismo e têm parcelas consideráveis de seus mercados (não só mercados, mas sobretudo, de seus aparelhos de produção) perfeitamente "internacionalizadas", sendo que no caso da Coréia do Sul as atividades industriais são essencialmente voltadas para a exportação sob a forma, analisada na seção 3 deste artigo, de "sub-empreitada". Sair do terreno do 
materialismo dialético é enveredar por generalizações vazias, substituir a análise concreta pela fraseologia sociológica...

\section{5 - O nacionalismo no "terceiro mundo"}

A política externa da ditadura militar está orientada a partir de Costa e Silva (a recusa de seu governo em assinar o tratado de nãoproliferação das armas nucleares é neste sentido bastante simbólica) em vista de fortalecer, pela concentração monopolista acelerada e pela reorganização do comércio exterior (que supunha evidentemente a reorganização da produção voltada para as exportações - a erradicação do café e o "export drive" de Delfim Netto, por exemplo) a posição do Brasil no interior do campo imperialista. A ditadura militar neste sentido tem tentado, com alguma perseverança, tirar partido das contradições interimperialistas como o atestam as constantes gestões governamentais no sentido de aumentar a participação relativa dos monopólios oeste-alemães, japoneses, italianos, franceses, etc. na indústria, na agricultura e na economia em geral. Dividir a dependência para atenuá-la a isto se reduz o "nacionalismo" do regime militar terrorista, em que pesem as manifestações colaboracionistas de certos setores da democracia burguesa e pequeno-burguesa escondendo sua inconsequência no combate anti-ditatorial atrás de uma fraseologia oca sobre a "soberania nacional". (Além de recentíssimos exemplos de Opinião e Movimento, há que lembrar as declarações de Franco Montoro e Ulysses Guimarães há um ano atrás, quando da viagem de Geisel à França e Inglaterra, condenando em nome da "solidariedade nacional" qualquer manifestação contra a tortura no Brasil).

Os limites da "soberania nacional" tal como a entende o fascismo militar são evidentes: a super-exploração do proletariado e a exploração monopolista das massas trabalhadoras em seu conjunto, a condição de país importador de capitais e portanto financeiramente dependente e, em que pesem recentes fanfarronices, a subordinação militar e diplomática à política internacional do imperialismo. 
É típico do nacionalismo burguês voltar-se contra as formas mais arcaicas da exploração imperialista (pilhagem de recursos naturais, intercâmbio desigual) na exata medida em que elas atingem a nação como um todo e por isso mesmo deixam encoberta a super-exploração do proletariado. Ora, mostramos anteriormente (ver Debate 25 e a seção 4 deste artigo) que embora historicamente anteriores, estas formas de exploração são estruturalmente secundárias em relação à extorsão direta de um sobre-trabalho extra, superior à taxa de exploração existente nas metrópoles imperialistas.

Governos burgueses, e mesmo governos reacionários semifeudais, como o dos Estados membros da OPEP (da Venezuela à Arábia Saudita passando pelo Irã) foram capazes de defender eficazmente suas riquezas naturais e os termos de intercâmbio com as metrópoles imperialistas, criando uma nova correlação de forças no mercado mundial capitalista. O exemplo da OPEP mostra com efeito a possibilidade de uma convergência limitada dos Estados do terceiro mundo com regimes sociais diferentes e até opostos na defesa de suas riquezas naturais e do preço de suas exportações. Mas mostra também que esta defesa, cujo caráter objetivamente progressista se deve em boa medida à posição anti-imperialista de alguns dos Estados membros (particularmente a Argélia, mas também o Iraque e a Líbia) tem e terá sempre pontos vulneráveis já que os governos reacionários (Arábia Saudita, Emirados Árabes, Irã) reduzem-na a uma mera questão de intercâmbio comercial, além de esbanjar suas rendas petroleiras suplementares no consumo suntuário das oligarquias locais ou, como é especialmente o caso da monarquia fascisante do Irã, no financiamento de um custoso aparelho repressivo que faz reinar o terror no interior do país.

A despeito, no entanto, de suas profundas contradições, a OPEP constitui para os exportadores de matérias-primas do terceiro mundo um exemplo a seguir e neste sentido, a declaração de Geisel em sua viagem ao Japão no ano passado ("Diálogo, não cartéis") condenando a tentativa de formação de uma associação de países exportadores 
de minério de ferro e atacando indiretamente a de exportadores de petróleo, dá a medida exata da perfeita identificação da política exterior da ditadura com a do campo imperialista em seu conjunto e portanto do verdadeiro significado da "defesa da soberania nacional" da qual a ditadura só se lembra quando se trata de defender o direito a continuar torturando soberanamente os nacionais. O que torna ainda mais grave a atitude de certos setores da oposição democrática que se desonraram politicamente ao colaborar com o regime nesta questão, como se fosse possível por entre parêntesis o terror ditatorial em nome da "não-ingerência" nos assuntos... dos torturadores.

A crise internacional do capitalismo cujas manifestações imediatas vêm assumindo, ao longo da presente década, cada vez maior gravidade (recessão, inflação, desemprego, acirramento da concorrência intermonopolista e intercapitalista), coloca os países capitalistas do terceiro mundo frente à alternativa de aceitarem passivamente as tentativas imperialistas visando a fazê-los sofrer o impacto principal das medidas de estabilização monetária e de reativação econômica anarquicamente adotadas ao sabor da evolução da conjuntura (restrição às importações, ao crédito internacional público e privado, guerra comercial etc.) ou de agirem no sentido de uma "nova ordem econômica internacional" preconizada pelos países mais avançados do movimento dos "não-alinhados". Não cabe aqui discutir o que significa ou pode vir a significar o combate econômico do terceiro mundo na defesa de seus legítimos interesses. O decisivo é o papel que nele desempenham e desempenharão os países de orientação socialista da África, do Mundo Árabe e da Ásia. Parte integrante da revolução socialista internacional, a revolução de libertação nacional dos povos até ontem submetidos à colonização imperialista se ressente duramente, no momento em que trava seus últimos combates contra o colonialismo, o racismo e o "apartheid", do oportunismo sem princípios dos dirigentes chineses sustentando a contrarrevolução africana e não mais hesitando em se aliar abertamente com os imperialistas numa 
política externa estreitamente nacionalista e em profunda contradição com as irreversíveis conquistas que o poder popular trouxe ao povo chinês.

É na exata medida em que cumpriu em grande parte os objetivos nacionais da luta revolucionária, que o combate dos povos do terceiro mundo se choca com a questão crucial do desdobramento anticapitalista da luta anti-imperialista. A forma fundamental da exploração imperialista é a exploração diferencial da força de trabalho dos proletários e semiproletários (estes últimos compreendendo os camponeses pobres que tiram parte de sua subsistência de minifúndios) do terceiro mundo. $\mathrm{O}$ anti-imperialismo das burguesias locais, quando existe, está essencialmente ligado à defesa das riquezas naturais e à luta pela melhoria dos termos do intercâmbio com as metrópoles imperialistas. Nos países onde se desenvolveu uma burguesia monopolista nacional (é o caso da Argentina, Brasil e Chile, para ficar só no "Cone Sul") e onde, de maneira geral, o desenvolvimento capitalista conferiu a estas burguesias locais uma base econômica própria de dominação de classe, podem surgir contradições, de variável importância, entre capitalistas nacionais e a alta finança imperialista, tanto no domínio bancário quanto no domínio industrial. No Brasil, estes conflitos de interesse têm sido relativamente frequentes e explicam tomadas de posição "nacionalistas" de certos setores da grande burguesia, cujos representantes mais lúcidos chegam até à defesa de uma certa estatização capitalista (o caso conhecido do ex-ministro Severo Gomes). Mas em absoluto não caracterizam uma situação de opressão da nação brasileira como tal, em absoluto não permitem a formação de uma frente patriótica que una os brasileiros como tais contra a dominação estrangeira.

A luta dos revolucionários contra a exploração imperialista está, num país onde já foi atingida a fase de concentração monopolista da produção, indissoluvelmente ligada à luta anti-monopolista. A defesa das riquezas humanas e materiais de nosso país supõe a realização da reforma agrária (a fim de que se produzam principalmente alimentos 
para o povo e não divisas para os ricos exportadores), a liberdade para os sindicatos (a fim de que os trabalhadores possam se opor eficazmente à super-exploração, quer seja realizada por monopólios estrangeiros, quer por nacionais) e a nacionalização democrática dos setores-chave da economia (a fim de que o poder democrático empenhado na construção do socialismo possa planificar a produção de maneira a colocá-la a serviço das necessidades locais, rompendo com a lógica do lucro monopolista). A defesa revolucionária da economia nacional não pode ser nem estreitamente obreirista (inclusive porque muitas vezes um monopólio estrangeiro tem condições de pagar melhores salários que as empresas nacionais) nem patrioteira (a exploração monopolista, quando efetuada por grandes capitalistas nacionais, não perde em seu caráter antissocial nem mesmo seu caráter antinacional, já que face à internacionalização da produção capitalista, a lógica da acumulação monopolista é determinada pela concorrência internacional dos capitais). 